\title{
Quality of education and socio-economic growth: The methods of Ishikawa, Deming and Pareto as tools for establishing cause-effect relationships
}

\author{
Artem Artyukhov ${ }^{1, *}$, Sergii Lyeonov ${ }^{2}$, Tetyana Vasylieva $^{3}$, and Jan Polcyn ${ }^{4}$ \\ ${ }^{1}$ Department of Marketing, Academic and Scientific Institute for Business, Economics and \\ Management, Sumy State University, Sumy, Ukraine \\ ${ }^{2}$ Department of Economic Cybernetics, Institute for Business, Economics and Management, Sumy \\ State University, Sumy, Ukraine \\ ${ }^{3}$ Department of Finance and Entrepreneurship, Institute for Business, Economics and Management, \\ Sumy State University, Sumy, Ukraine \\ ${ }^{4}$ Stanisław Staszic University of Applied Sciences in Piła, Department of Economics, Piła, Poland
}

\begin{abstract}
The article is devoted to selecting the methods of finding the cause-effect relationships in simulating the system "quality education" and to determining the factors influencing the quality of education in the socioeconomic development of both the university and education stakeholders. The rationale for selecting the tools for studying cause-and-effect relationships in modelling the system is formulated. It is shown that for the system "quality of education" it is possible to use analysis tools that were previously inherent only in technical systems. An integrated approach to assessment using the Pareto method, Ishikawa method, cycle and Deming principles is proposed. Each stage of studying cause-and-effect relationships is considered; the relationship between the stages and the tools used is shown. The consistent application of these tools for the "quality of education" system has not yet been implemented, which determines the novelty of this work. As a result of implementing such a complex algorithm, the system approaches the external quality assessment in its optimal state with a clearly expressed optimization criterion and methods of achieving it.
\end{abstract}

\section{Introduction}

The research of causal relationships in constructing the models of systems based on multifactorial influence is one of the most effective tools in ensuring quality and forecasting further development. The directed influence on concrete indicators for maintaining predictable result allows allocating the significant factors whose action can be defining, to consider in detail an "internal" component of the indicator, to create algorithm of working with this indicator for the purpose of increasing or lowering its value.

* Corresponding author: a.artyukhov@,pohnp.sumdu.edu.ua 
The system of quality assurance in education and assessment of its impact on the socioeconomic growth of the territory are also an object for modelling causal relationships. The specific feature of this system is its "non-physicality" which is manifested in the absence of material execution of the system in the form of equipment, installation, and other set of physical objects. However, the system has a "technological" component: clearly defined optimization criteria, the algorithm for implementing each of the stages of the "technological" process, the decision-making algorithm, etc. Thus, when modelling the functioning of the system "quality of education", in addition to the tools for describing exclusively intangible objects, you can also refer to applying techniques used to describe technical systems.

The study of causal relationships involves the use of reliable tools that have proven themselves not only as theoretical but also as "solvers" of practical cases. This paper proposes the integrated use of three tools: the Pareto method, the Ishikawa diagram, and the Deming cycle.

The Pareto method [1] allows determining the most significant indicators that are applied to assess the process of ensuring the quality of education and its socio-economic impact. Based on the results of these indicators, a detailed analysis of each indicator as a chain "content - methods - tools - educational environment" is carried out using the Ishikawa diagram [2]. The Deming cycle [3] completes the study of causation by developing an action plan, an algorithm for its implementation, monitoring the achievement of goals and adjusting the plan if necessary.

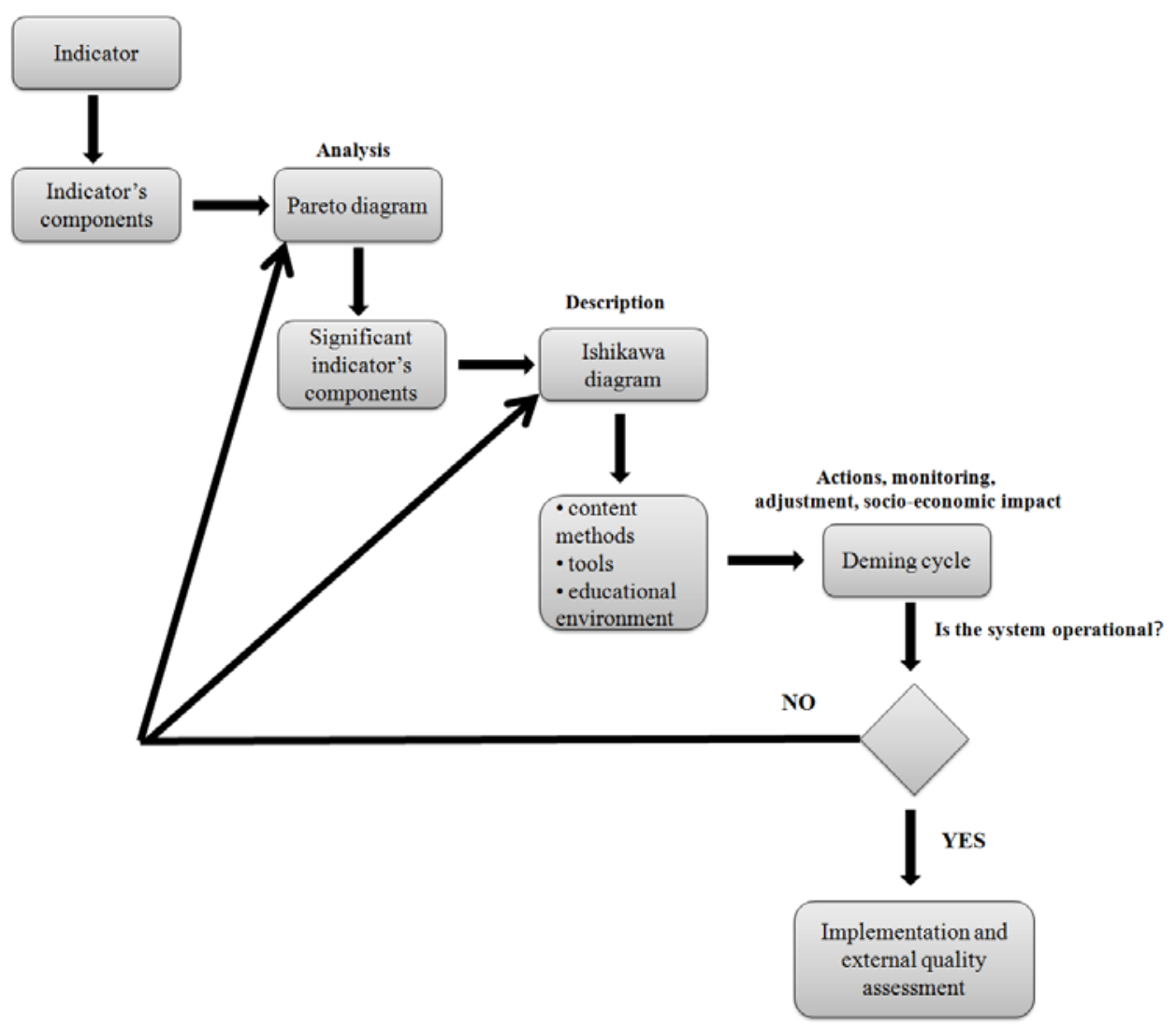

Fig. 1. An algorithm for modelling the system "quality of education". 
The purpose of the work is to model causal relationships in the system of "quality of education" with the definition of the level of its socio-economic impact. Consistent application of these tools for the "quality of education" system has not been implemented so far, which determines the novelty of this work. As a result of implementing such a complex algorithm, the system approaches the external quality assessment in its optimal state with a clear optimization criterion and methods for achieving it. This fact determines the practical significance of the presented work.

The algorithm for using the presented set of tools is illustrated in Figure 1.

\section{Literature Review}

For the modelling process, there can be used various data and information, approaches to describing certain processes related to the quality of education and the economic development of the state. Among others, the following areas can be distinguished:

- state regulation of economic security and innovation [4-9];

- digitalization of education [10-11];

- rating indicators of universities [12];

- participation in international projects [13-15];

- specific features of teaching at different levels of education [16-22];

- successful examples of innovations in education and economics [23-31];

- knowledge management and criteria for the activity of an entrepreneurial university $[32,33]$;

- the socio-economic impact of the quality of education [34];

- education and sustainable development goals [35-41];

- the development management [42-45].

This list is not exhaustive; each indicator has its own set of sub-criteria. Within the framework of this work, attention will be paid to describing the algorithm for a specific criterion "international activity".

\section{Research Methodology, Results and Discussion}

\subsection{A Pareto chart}

An example of constructing a Pareto chart to identify the reasons for the decline in the indicator "international relations" within the framework of the education quality system is presented in Table 1 and Figure 2. The importance of each reason is assessed by a 100-point scale.

The choice of the method for constructing a Pareto diagram for reasons, rather than for performance results, is explained by the fact that individual reasons can be systemic in nature, while results can depend on several reasons at the same time. The number of points for assessing the importance of the problem was taken on the basis of analysing indicators of international ratings, international organizations, and databases.

As can be seen from the data in Table 1 and Figure 1, a decline in international activity as an element of quality assurance in education comes down to almost $80 \%$ influence of four reasons: lack of international partners, low publication activity in high-impact publications, low level of English proficiency, lack of funding from foreign donors.

The further stage of modelling the system will be presented in the analysis, for example, of reason 2 "low publication activity in high-rating publications". 
Table 1. The data for building a Pareto chart

\begin{tabular}{|c|c|c|c|c|c|}
\hline № & Reason & $\begin{array}{l}\text { Assessment of } \\
\text { the importance } \\
\text { of the cause in } \\
\text { points }\end{array}$ & $\begin{array}{l}\text { Accumulated } \\
\text { points }\end{array}$ & $\begin{array}{c}\text { Deposit } \\
\text { of each } \\
\text { reason, } \\
\% \\
\end{array}$ & $\begin{array}{l}\text { Cumulative } \\
\text { deposit, \% }\end{array}$ \\
\hline 1 & $\begin{array}{l}\text { Lack of international } \\
\text { partners }\end{array}$ & 85 & 85 & 25 & 25 \\
\hline 2 & $\begin{array}{l}\text { Low publication } \\
\text { activity in high- } \\
\text { ranking publications }\end{array}$ & 80 & 165 & 24 & 49 \\
\hline 3 & $\begin{array}{l}\text { Poor English } \\
\text { proficiency }\end{array}$ & 65 & 230 & 19 & 68 \\
\hline 4 & $\begin{array}{l}\text { Lack of funding from } \\
\text { foreign donors }\end{array}$ & 30 & 260 & 9 & 77 \\
\hline 5 & $\begin{array}{l}\text { Problems of finding } \\
\text { universities for } \\
\text { academic mobility }\end{array}$ & 20 & 280 & 6 & 83 \\
\hline 6 & $\begin{array}{l}\text { A small number of } \\
\text { teachers from abroad }\end{array}$ & 15 & 295 & 4,5 & 87,5 \\
\hline 7 & $\begin{array}{l}\text { Not enough English } \\
\text { courses }\end{array}$ & 15 & 310 & 4,5 & 92 \\
\hline 8 & $\begin{array}{l}\text { Reluctance to engage } \\
\text { in international } \\
\text { activities }\end{array}$ & 14 & 324 & 4 & 96 \\
\hline 9 & $\begin{array}{l}\text { Quality of work of the } \\
\text { university department } \\
\text { of international } \\
\text { relations }\end{array}$ & 13 & 337 & 4 & 100 \\
\hline
\end{tabular}

100

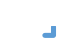

90

80

70

$\rightarrow 68$

- 49

50

40

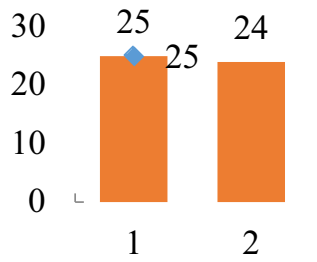

19
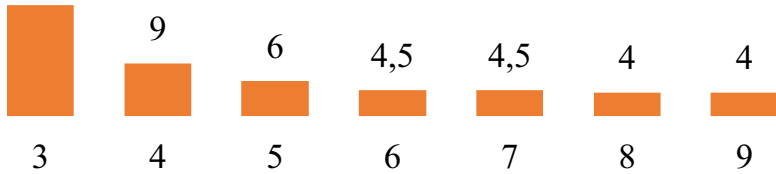

Fig. 2. A Pareto chart. 


\subsection{An Ishikawa diagram}

A detailed analysis of the reasons for "low publication activity in high-ranking publications" made it possible to single out the main factors affecting the quality of education itself and the quality of scientific research. For convenience, each of the quality elements is presented in a separate diagram.

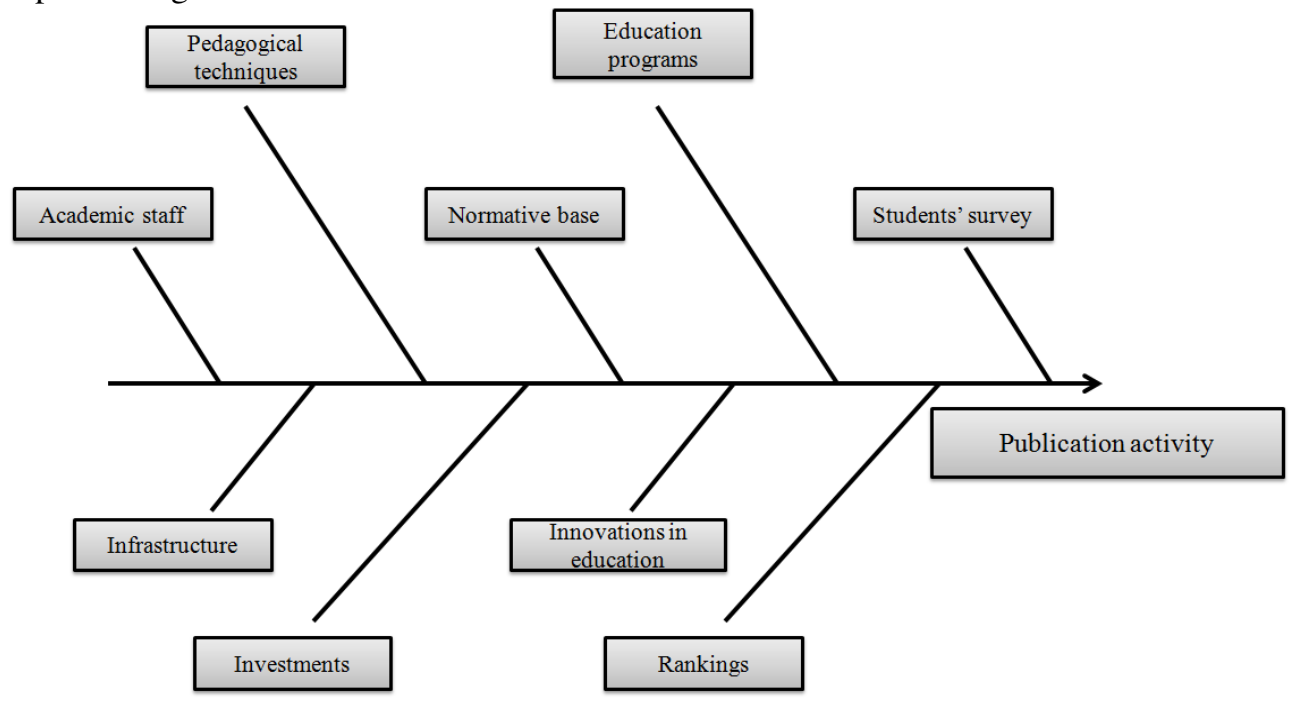

Fig. 3. The Ishikawa diagram 1: quality of education.

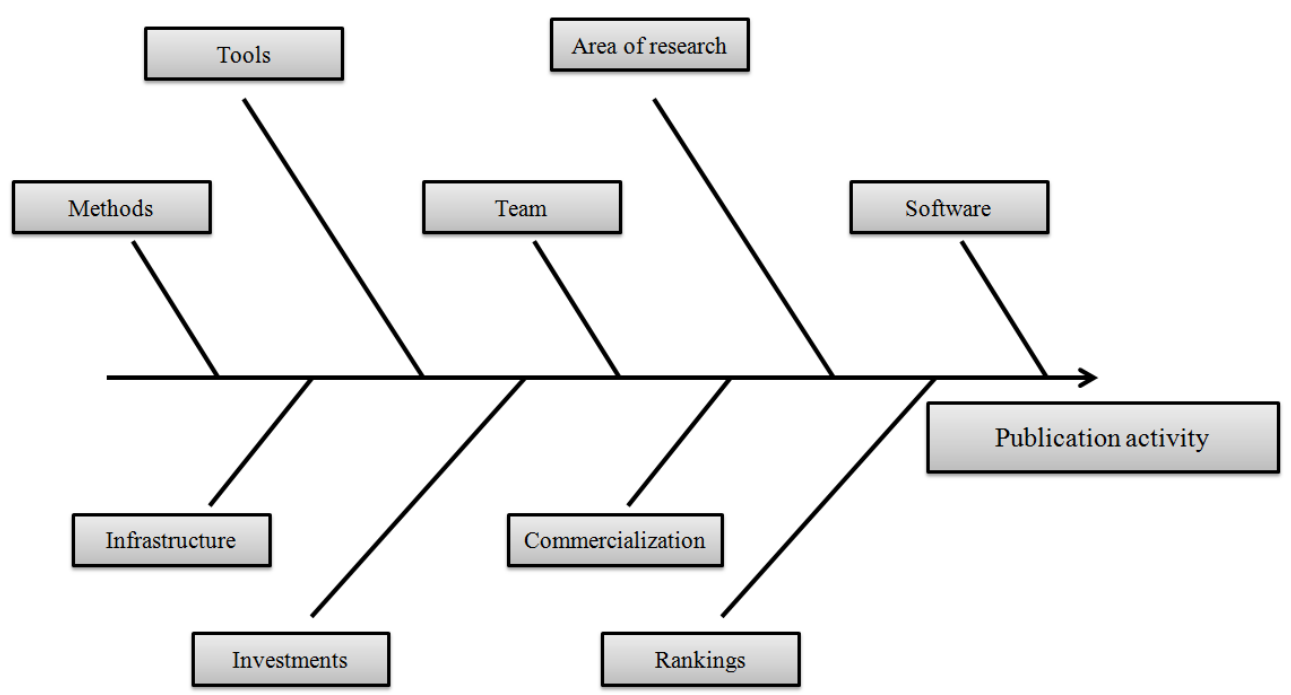

Fig. 4. The Ishikawa diagram 2: quality of scientific research.

In the Ishikawa diagram, two blocks should be distinguished: the local block of performers, methods and tools for their work, and the university block for providing infrastructure. As shown in Figures 3 and 4, some of the reasons are the same, since they depend on the university's financial stability and its provision of rating indicators in international rankings. This fact is the reason for searching the tools for the mutual merger of the main stakeholders of education to increase the financial independence of the university, 
which, in turn, depends on the degree of socio-economic influence on the stakeholders and the provision of high-quality educational and scientific services to them. The Ishikawa's method could be the final one in the process of searching for cause-and-effect relationships when modelling the system of education quality, but its drawbacks (for analysing complex problems, it is too vague and voluminous; it is impossible to imagine cause-and-effect relationships in connection with each other; there is no coverage of reasons in their interaction, and time dependence [43]) do not allow developing a strategy for eliminating the identified problems. Analysis of the problems inherent in each of the blocks (local and university) and the specifics of quality assurance (quality of education and the quality of scientific research) makes it possible to develop a set of measures to solve problems, an algorithm for implementing the complex, an algorithm for control and adjustment. This stage is presented in the form of the Deming cycle.

\subsection{The Deming cycle}

This stage will be described using both the image of the Deming Cycle (PDCA [43] (Figure 5) and applying its principles [44] to the problem of ensuring the quality of education and evaluating the socio-economic factors of the mutual influence of the system and stakeholders [45].

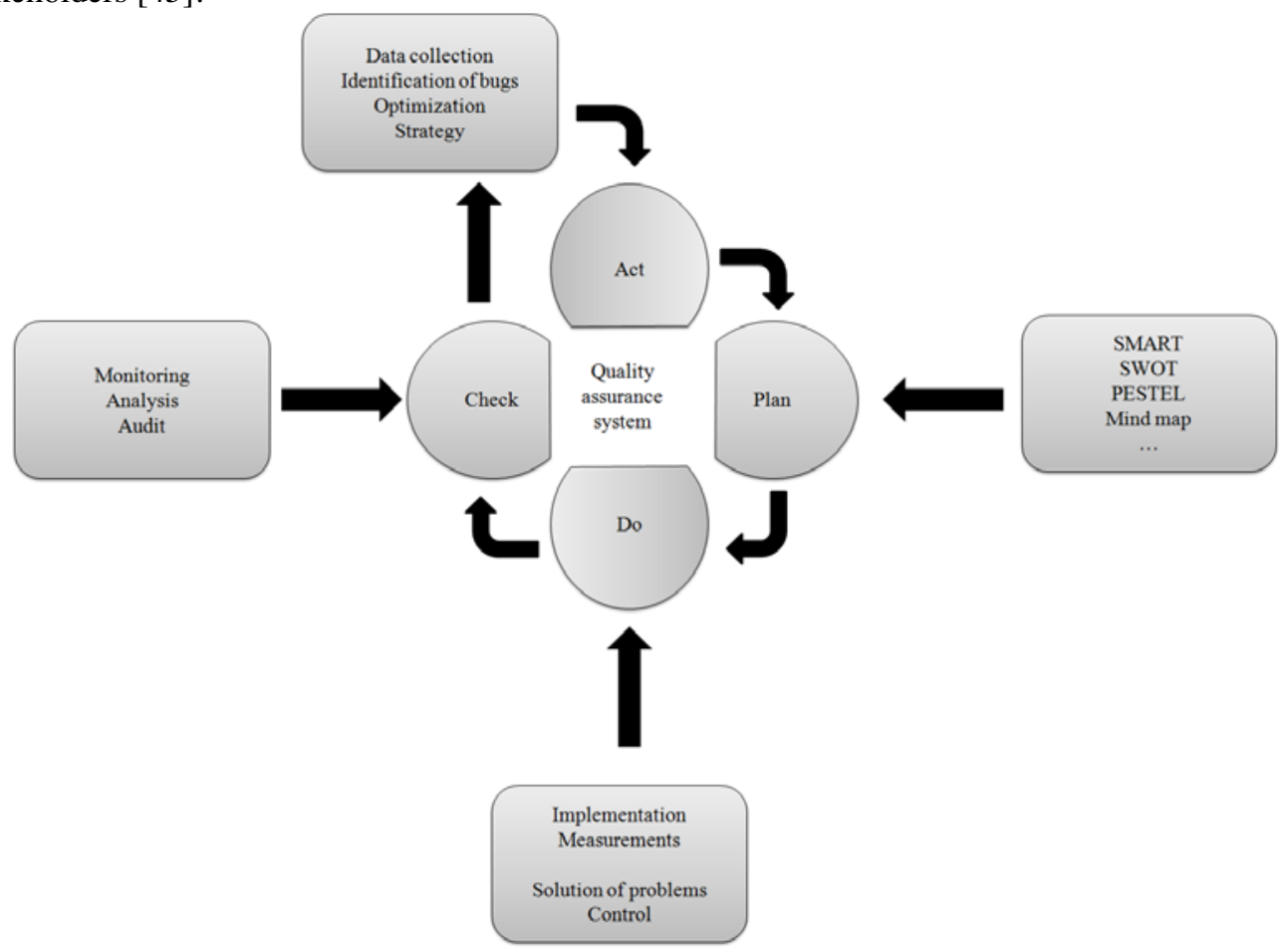

Fig. 5. The Deming Cycle.

Application of the Pareto principles to the quality of education system:

1. Consistency of purpose: continuous improvement of the education quality to ensure its competitive advantages in the market of educational and scientific services.

2. Changing the philosophy of achieving the goal: using a strategy of advanced development. 
3. Minimizing the dependence on the quality control: embedding quality indicators directly into the product (educational services, scientific developments). Intermediate quality control is carried out when analysing the results of the survey of the main stakeholders.

4. Diversifying educational and scientific services: a targeted work with each stakeholder of the educational program or scientific direction.

5. Improving the system continuously: developing and modernizing the regulatory framework for the quality assurance of educational and scientific activities.

6. On-the-job training: continuous improvement of the university's human resources skills through internal and external professional development programs.

7. Teaching leadership skills: creating a teamwork environment to deliver performance and overcome challenges.

8-9. Creating a positive climate and removing barriers among employees: interdisciplinary and cross-disciplinary educational programs and research.

10. A lack of slogans in work: everything is subordinated only to implementing the university's development strategy in general and specific directions.

11. Introducing innovations and improving processes: applying incentive mechanisms for employees that will increase their motivation to innovate.

12. Availability of an action plan: each participant in the educational and scientific process must understand their tasks in achieving the overall result.

\section{Conclusions}

A complex algorithm for studying cause-and-effect relationships allows establishing the causes of a negative trend in changing a particular indicator and provides an algorithm for influencing this trend to obtain a positive result. The synergy of the tools presented in this work makes it possible to develop an unambiguous and time-specific university development strategy to ensure the quality of education. The same algorithm makes it possible to assess the university's degree of mutual socio-economic influence and stakeholders due to diversification (as applied to non-financial terms) of the sources of achieving goals.

Acknowledgments: This research was funded by the grant from the Ministry of Education and Science of Ukraine "Reforming the lifelong learning system in Ukraine for the prevention of the labour emigration: a coopetition model of institutional partnership" (reg. No 0120U102001), "Convergence of economic and educational transformations in the digital society: modelling the impact on regional and national security" (reg. No 0121U109553).

\section{References}

1. D. Ghosh, and Debjani Chakraborty, Operations Research Letters, 42(8), 514 (2014)

2. D.D. Shinde, S.Ahirrao, R. Prasad, Wireless Personal Communication, 100, 653 (2018)

3. R. Moen, and C. Norman, Proceedings of the 7th ANQ Congress, 1 (2009)

4. V. Levchenko, A. Boyko, T. Savchenko, V. Bozhenko, Yu. Humenna, and R. Pilin, Marketing and Management of Innovations, 4, 364 (2019)

5. O. Lyulyov, T. Pimonenko, A. Kwilinski, H. Dzwigol, M. Dzwigol-Barosz, V. Pavlyk, \& P. Barosz. Energies, 14(2) (2021).

6. M. Bublyk, V. Koval, O. Redkva. Marketing and Innovation Management, 4, 229-240. (2017).

7. O. Akimov, V. Troschinsky, M. Karpa, V. Ventsel, L. Akimova. Journal of Legal, Ethical and Regulatory Issues, 23(3), 1-7. (2020).

8. Y. Us, T. Pimonenko, O. Lyulyov. Polityka Energetyczna, 23(4), 49-66 (2021).

9. M. Kordos, M. Marketing and Management of Innovations, 3, 341-353. (2019). 
10. C.G. Cosmulese, V. Grosu, E. Hlaciuc, A. Zhavoronok, Marketing and Management of Innovations, 3, 242 (2019)

11. I. Vakulenko, L. Saher, O. Lyulyov, T. Pimonenko. in Proceedings of E3S Web of Conferences, 250 (2021)

12. S. Kvitka, G. Starushenko, V. Koval, H. Deforzh, and O. Prokopenko, Marketing and Management of Innovations, 3, 60 (2019)

13. Y. Petrushenko, N. Kostyuchenko, D. Smolennikov, and A. Vorontsova, Problems and Perspectives in Management, 15(3), 183 (2017)

14. P. Gallo, B. Mihalcova, O. Vegsoova, T. Dzurov-Vargova, N. Busova. Marketing and Management of Innovations, 2, 11-20. (2019).

15. D.T. Frederick, K. Kasztelnik, Financial Markets, Institutions and Risks, 4(4), 5 (2020)

16. K. Onopriienko, V. Onopriienko, Y. Petrushenko, and I. Onopriienko, E3S Web of Conferences, 234, 00002 (2021)

17. Y. Kharazishvili, A. Kwilinski, A., O. Grishnova, H. Dzwigol. Sustainability, 12(21), 8953. (2020)

18. H. Dzwigol, M. Dzwigol-Barosz, R. Miskiewicz, A. Kwilinski, A. Entrepreneurship and Sustainability Issues, 7(4), 2630-2644. (2020).

19. M. Soliman, O. Lyulyov, H. Shvindina, R. Figueiredo, T. Pimonenko. European Journal of Tourism Research, 28 (2021).

20. H. Dzwigol, H. Marketing and Management of Innovation, 1, 324-335. (2021).

21. M.S. Ayad, A.A. El-Aziz, SocioEconomic Challenges, 2(2), 49 (2018)

22. A.D. Miller, Business Ethics and Leadership, 4(4), 28 (2020)

23. L. Sineviciene, O. Shkarupa, L. Sysoyeva, SocioEconomic Challenges, 2(2), 81 (2018)

24. I. Vakulenko, L. Saher, L. Syhyda, S. Kolosok, A. Yevdokymova. Paper presented at the E3S Web of Conferences, , 234

25. A. Bondarenko, L. Zakharkina, L. Syhyda, L. Saher. International Journal of Sustainable Development and Planning, 15(4), 439-449 (2020).

26. L. Melnyk, L. Sineviciene, O. Lyulyov, T. Pimonenko, I. Dehtyarova. Problems and Perspectives in Management, 16(1), 105-114. (2018).

27. A. Rosokhata, O. Rybina, A. Derykolenko, V. Makerska. Research in World Economy, 11 (4), 42-52 (2020).

28. A. Rosokhata, M. Minchenko, L. Khomenko, O. Chygryn. Paper presented at the E3S Web of Conferences, , 250 (2021)

29. O. Chygryn, A. Rosokhata, O. Rybina, N. \& Stoyanets. Paper presented at the E3S Web of Conferences, , 234 (2021).

30. L. Matos, K. Kasztelnik, Business Ethics and Leadership, 5(1), 6 (2021)

31. B.A. Brimah, W.D. Olanipekun, A.G. Bamidele, M. Ibrahim, Financial Markets, Institutions and Risks, 4(2), 34 (2020)

32. F. Vidic, SocioEconomic Challenges, 3(2), 37 (2018)

33. L. Akimova, O. Akimov, T. Maksymenko, Z. Hbur, V. Orlova. Academy of Entrepreneurship Journal, 26(3), 1-8. (2020).

34. O. Pavlenko, V. Martynets, O. Dreval, and D. Smolennikov, Quality - Access to Success, 21(176), 81 (2020)

35. A. Vorontsova, H. Shvindina, T. Mayboroda, H. Mishenina, and I. Heiets, Problems and Perspectives in Management, 18(4), 275 (2020)

36. I. Sotnyk, T. Kurbatova, V. Dashkin, V., Y. Kovalenko. International Journal of Sustainable Energy, 39(3), 218-239. (2020).

37. N. Letunovska, O. Lyuolyov, T. Pimonenko, V. Aleksandrov. Paper presented at the E3S Web of Conferences, , 234.

38. A. Teletov, S. Teletova, N. Letunovska. Periodicals of Engineering and Natural Sciences, 7(2), 458-465 (2019). 
39. N. Letunovska, L. Saher, T. Vasylieva, S. Lieonov. Paper presented at the E3S Web of Conferences, 250 (2021).

40. L. Saher, L. Syhyda, O. Korobets, T. Berezianko. Paper presented at the E3S Web of Conferences, , 234

41. Y. Petrushenko, A. Vadym, A. Vorontsova, and O. Ponomarenko, E3S Web of Conferences, 202, 03005 (2020)

42. N. Stukalo, M. Lytvyn, Y. Petrushenko, and Y. Omelchenko, E3S Web of Conferences, 211, 01029 (2020)

43. M.S. Desai, and R.A. Johnson, SAM Advanced Management Journal, 78, 51 (2013)

44. V. Firescu, and J. Popescu, International Journal of Economics \& Business Administration, 0(4), 44 (2015)

45. M.J. Taylor, C. McNicholas, C. Nicolay, A. Darzi, D. Bell, and J E. Reed, BMJ quality \& safety, 23(4), 290 (2014) 